\title{
Sweet Potato Value Chain Analysis Reveals Opportunities for Increased Income and Food Security in Northern Ghana
}

\author{
Issah Sugri, ${ }^{1,2}$ Bonaventure Kissinger Maalekuu, ${ }^{1}$ Eli Gaveh, ${ }^{1}$ and Francis Kusi ${ }^{2}$ \\ ${ }^{1}$ Department of Horticulture, College of Agriculture and Natural Resources, Kwame Nkrumah University of Science and Technology, \\ Kumasi, Ghana \\ ${ }^{2}$ Council for Scientific and Industrial Research, Savanna Agricultural Research Institute, P.O. Box 46, Bawku, Ghana
}

Correspondence should be addressed to Issah Sugri; isugri22@gmail.com

Received 29 July 2017; Accepted 4 October 2017; Published 2 November 2017

Academic Editor: Innocenzo Muzzalupo

Copyright (C) 2017 Issah Sugri et al. This is an open access article distributed under the Creative Commons Attribution License, which permits unrestricted use, distribution, and reproduction in any medium, provided the original work is properly cited.

\begin{abstract}
Sweet potato has gained prominence due to its ability to adapt to wide production ecologies and yield response to minimal external inputs. Orange-fleshed cultivars in particular have immense potential to improve household income and nutrition in sub-Saharan Africa. However, the sweet potato value chain (SPVC) is not well-developed in many producing countries. The study was conducted in two regions to characterize the production operations as well as identify opportunities to propel the SPVC in Northern Ghana. Data were collected using mixed methods including structured questionnaires via face-to-face interviews. Analysis of strengths, weaknesses, opportunities, and threats (SWOT) was conducted at multistakeholder platforms with different actors. Gross margin profit and benefit-cost ratios were determined by using six cost variables. Overall, the industry was largely a fresh produce market, targeting food vendors, processors, and direct selling to wholesalers, retailers, and household consumers. The SWOT analysis revealed wide-ranging opportunities including favourable production ecologies, processing options, and insatiable local and international markets. The institutional actors need to network the primary actors to synergistically operate with a collective profit motive. The most prioritized production constraints such as access to seed, cost of chemical fertilizer, short shelf-life, field pests and diseases, and declining soil fertility should be addressed.
\end{abstract}

\section{Introduction}

Sweet potato (Ipomoea batatas L. Lam) is currently ranked as the seventh most important crop in the world with a total production of 103 million tonnes in 2013 [1]. Asia accounts for close to $76 \%$ of world production, followed by the African continent (19.5\%). The top five producers are China, Nigeria, Uganda, Indonesia, and the United Republic of Tanzania [1]. China is the highest producer with production figures around 75.6 million tonnes, followed by Tanzania and Nigeria that produce up to 3.57 and 2.73 million tonnes, respectively. Sweet potato is among five most important crops in 40 developing countries beside rice, wheat, maize, and cassava [2].

Over the last two decades or more, sweet potato has gained prominence due its short growth cycle and ability to survive in diverse agroecologies and water stress soils $[3,4]$. These traits project sweet potato high among resource-poor farmers as yields of 15 to $50 \mathrm{t} / \mathrm{ha}$ can be obtained with minimum use of external inputs. Research evidence suggests that orange-fleshed sweet potato (OFSP), in particular, could play a role in combating vitamin A deficiency among children and women in Africa and parts of Asia [5,6]. Just one small root (100-125g) of most OFSP cultivars supplies the recommended daily allowance of vitamin A for children under five years of age [6]. Even at low yields of about $6 \mathrm{t} / \mathrm{ha}$, just $500 \mathrm{~m}^{2}$ of land can generate the annual requirement of vitamin A for a family of five. In addition, it is a remedial crop for crop-livestock farmers because of its high root and fodder productivity with minimal external inputs [7]. For smallholder crop-livestock farmers as well, sweet potato forage yields command additional importance [8].

In Ghana, sweet potato is the fourth most important root crop after yam (Dioscorea spp.), cassava (Manihot esculenta Crantz), and Taro (Colocasia spp.). The crop is widely cultivated in the Northern, Upper East, Upper West, 
Central, and Volta Regions by smallholder farmers [9]. Annual production is estimated at 0.132 million tonnes produced on approximately 9,622 ha of arable land [10]. Low yields of around $8 \mathrm{t} /$ ha compared to the yield potential of $24 \mathrm{t} / \mathrm{ha}$ are recorded. Until now, the vast majority were low yielding white-fleshed cultivars which have low or no betacarotene. However, the Root and Tuber Improvement and Marketing Programme (RTIMP) and other partners have made tremendous strides at introducing OFSP and other high yielding cultivars particularly with resistance to the sweet potato virus disease.

However, widespread production and utilization challenges such as low yields, use of local cultivars, poor access to vines, and field pests and diseases as well as postharvest storage, preservations, and utilization issues still exist [11-14]. Shortage of seed at planting time is still a chronic challenge across West Africa. During field production, a complex of biotic constraints, including nematodes, viral diseases, soil arthropods, weevils, and foliage feeding insects have been reported $[12,13]$. Overall, the African sweet potato weevils (Cylas brunneus F. and C. puncticollis Boheman) pose the most threat, followed by the sweet potato butterfly (Acraea acerata Hew.) and the clearwing moth (Synanthedon spp.) [13]. Preserving the fresh produce shelf-life remains a major challenge to farmers, traders, and consumers across subSaharan Africa $[11,14,15]$. High losses in quantity and quality are recorded as the farmers and traders lack the capacity to use cold chain facilities to reduce physiological and microbial breakdown. This leads to seasonal glut and low prices which affect the economic returns to actors. Another constraint is the low patronage compared to other root crops which is attributed to lack of end-user preferred cultivars that allow for daily consumption as a staple [16].

This study sought to achieve a balance between increased crop production and the development of downstream activities such as processing and marketing in a coordinated manner to ensure that productivity increases benefit for all the chain actors. The value chain approach embraces all key actors and activity interventions within an industry that have the potential of propelling sustainable competitive advantage [17]. This study assessed the sweet potato value chain (SPVC) to unlock its potential of providing income and food security by identifying (1) challenges and prospects from the production to utilization stages and (2) strategies to propel the development and dissemination of improved technologies as well as innovations that benefit all chain actors.

\section{Methodology}

2.1. Study Area. The study was conducted in the Northern and Upper East Regions of Ghana. The study area is considered as a major production hub of cereals (maize, sorghum, millet, and rice) and legumes (cowpea, soybean, groundnut, and Bambara nut) and vegetables (onion, tomato, pepper, okra, and watermelon). However, the area is poorly endowed with natural resources and the income per capita falls below the national average. The zone constitutes the most disadvantaged regions and has been described as part of the most poverty-stricken spots in Ghana. The incidence of poverty, malnutrition, and stunting among children under five years is higher with more than 680,000 people considered as moderately food insecure and 140,000 classified as severely food insecure [18]. Maize-based cropping system is dominant in the region due to its high yield potential per unit area compared to the traditional sorghum or millet. Average land holding ranges from 1 to 4 ha per household though farm sizes of up to 15 ha are recorded for a few endowed households for crops such as maize, rice, and yam. Dry season vegetable production is another major source of income to many households.

2.2. Field Survey. The field survey was conducted in six districts: Bawku, Pusiga and Garu-Tempane in the Upper East Region and Tamale, Tolon, and Kumbungu in the Northern Region. In all, 246 farmers were covered using a multistage sampling approach. The districts and communities were purposively sampled due to their relative involvement in sweet potato farming and the farmers were randomly sampled. A study unit was defined as a farmer who lives and cultivates sweet potato within the selected communities or ever cultivated sweet potato in last three years. The sample size was determined using the following formula:

$$
\begin{aligned}
& n=\frac{Z^{2} P Q}{D^{2}} \\
& n=\frac{3.8416 * 0.8 * 0.2}{0.0025}=245.9, n=\frac{0.614656}{0.0025}=245.9
\end{aligned}
$$

where $Z$ is confidence level of 95\% (standard deviation of 1.96); $P$ is estimated prevalence of farmers in the project area $(80 \%)$, that is, the proportion of the target population with a given characteristic (sweet potato farmers in the community); $Q$ is $1-P ; D$ is margin of error of $5 \%$.

Data were collected by using mixed methods including structured questionnaires via face-to-face interviews. The questionnaire captured information on sociodemographic characteristics including age, gender, household size, and education. Additional information was captured on scale of production; source of seed; production and harvesting operations; storage and utilization; integrated pest management strategies; and training needs assessment. Other qualitative data were collected by employing participatory rural appraisal tools such as focus group discussions and key informant interviews. Additional information generated was seasonal calendar, market analysis, and multistakeholder mapping. During these sessions, strategies to improve the dissemination of technologies were discussed to push the SPVC to sustain competitive advantage.

2.3. Value Chain Analysis. The main actors in the study included farmers, traders, transporters, processors, consumers, research institutions, Ministry of Food and Agriculture, nongovernmental organizations (NGOs), and donor agencies. Analysis of strengths, weaknesses, opportunities, 
and threats (SWOT) of the SPVC was conducted at multistakeholder platforms in the six study districts. The information generated from the SWOT analysis was further processed to identify management strategies to propel the SPVC. Stakeholder mapping was conducted to identify linkages among the actors as well as their possible roles and opportunities for collaboration.

2.4. Problem Census and Prioritization. Problem census and prioritization was conducted by asking respondents to enumerate the constraints they encounter in the production to marketing of sweet potato. The respondents were further asked to rank the constraints from the most to least important. The Kendall's coefficient of concordance $(W)$ statistical procedure was employed to test data significance and strength of agreement among the responses. Kendall's coefficient of concordance $(W)$ measures the agreement among several $(m)$ quantitative or semiquantitative variables that are assessing a given set of $n$ objects of interest [19]. The analysis provides a distribution-free test of independence and measures the strength of relationship between two variables being compared. The mean score for each problem was computed and the problem with least score was ranked as the most constraining factor. The coefficient of concordance $(W)$ was estimated by using the relation:

$$
W=\frac{S}{(1 / 2) K^{2}\left(N^{3}-N\right)},
$$

where $S$ denotes the sum of squares of deviations from rank means. $S$ is expressed as

$$
S=\sum\left(R_{j} \frac{\sum R_{j}}{N}\right)^{2},
$$

where $R_{j}$ is the sum of ranks for the $j$ th constraint; $K$ is the number of ranking panel (respondents); $N$ is the number of constraints which are being ranked.

$$
\frac{1}{2} K^{2}\left(N^{3}-N\right)
$$

is the maximum possible sum of squared deviations which is expected to occur in the case of perfect agreement among $K$ ranking criteria.

2.5. Cost, Output, and Revenue. We computed for gross margin profit, gross margin percentage, and benefit-cost ratio to determine if sweet potato production was profitable in the study area. Six variable cost inputs (land tillage, seed, sowing or planting, weeding, fertilizer, and spraying) were used to compute the cost of production.

Gross margin profit $(P)$ was calculated as the difference between the cost of production $(C)$ and the selling price or revenue $(R)$ (expressed as: $P=R-C$ ).

Gross margin percentage $(G)$ was computed as the profit $(P)$ divided by the selling price or revenue $(R)$, expressed mathematically as (Net sales - Cost of goods sold)/Net sales.

Benefit-cost ratio (BCR) was determined by dividing the total value of benefits by total costs. Benefit-cost ratio attempts to identify the relationship between cost and benefits of a proposed project. If the project has a BCR greater than 1, it indicates that the net present value (NPV) of the project benefits outweighs the NPV of the costs. Therefore, the project should be considered to be viable if the BCR is greater than 1 .

2.6. Data Analysis and Reporting. The sociodemographic data generated was analysed by using the Statistical Package for Social Sciences (SPSS Edition 20). Descriptive statistics involving frequencies and means were employed in data reporting. Results were then presented in tables, graphs, and flow diagrams from which inferences were drawn.

\section{Results and Discussion}

3.1. Sociodemographic Characteristics. Table 1 summarizes the sociodemographic characteristics such as gender, educational level, marital status, and household agricultural income in both regions of study. The gender distribution was $15 \%$ female and $85 \%$ male farmers with an average household size of $7 \pm 5$ individuals. Majority of the respondents $(78.8 \%)$ had no formal education; only 12.9 and $6.3 \%$ had basic and secondary education, respectively. The annual agricultural related income of $60 \%$ of respondents ranged from $\mathrm{GHC100}$ to 1000 whereas $18.3 \%$ respondents recorded income above GHC2000. The primary occupation of respondents (99\%) was mainly crop production, with varying involvement in livestock rearing. The group discussions revealed that more than $10 \%$ migrated to southern Ghana when agricultural activities declined at the off-season.

3.2. Production Operations. The sweet potato seasonal calendar (Table 2) showed three patterns of activities, namely, the establishment of conservation and secondary nurseries; field production operations; and postharvest, marketing, and utilization period. Majority of respondents (52.5\%) were smallholder farmers producing on about 0.5 ha of land (Table 3). Most farmers were growing both local and improved cultivars but often recycled the seed for 3-5 years in their home gardens. A similar study in Kenya showed that although a high proportion of farmers $(79 \%)$ were aware of the importance of clean seed, only $4.5 \%$ actually resorted to use of certified seed [20]. In sweet potato production, seeds obtained from certified vine multipliers is considered as certified. The price of certified seed was more than double that of recycled farmer seed; the latter was readily obtainable. Just a little around $30 \%$ of the respondents in this study stored the roots beyond 4 weeks after harvest for utilization.

3.3. Production Cost, Output, and Revenue. The focus group discussions showed that sweet potato production system is not well-developed due to a complex of socioeconomic constraints including limited land and poor soil fertility. The production operations were largely at smallholder level involving little mechanized implements. The average land area was 0.5 ha, with a range of 0.2 to 4 ha across the two regions (Table 4 ). The harvested produce, which ranged from 315 to $3308 \mathrm{~kg}$, was consumed or marketed within 4 weeks 
TABLE 1: Sociodemographic characteristics of the respondents (\% responding).

\begin{tabular}{|c|c|c|c|c|}
\hline Demographic characteristics & Description & Northern region & Upper East region & Total \\
\hline \multirow{2}{*}{ Gender } & Male & 80.7 & 90.0 & 85.0 \\
\hline & Female & 19.3 & 10.0 & 15.0 \\
\hline \multirow{4}{*}{ Age (years) } & $<20$ & 1.7 & 3.3 & 2.5 \\
\hline & $20-45$ & 64.7 & 51.7 & 58.3 \\
\hline & $46-60$ & 24.4 & 39.2 & 31.7 \\
\hline & $>60$ & 9.2 & 5.8 & 7.5 \\
\hline \multirow{4}{*}{ Marital status } & Single & 13.4 & 12.5 & 12.9 \\
\hline & Married & 84.9 & 86.7 & 85.8 \\
\hline & Separated & 1.7 & - & 0.8 \\
\hline & Widowed & - & 0.8 & 0.4 \\
\hline \multirow{4}{*}{ Educational level } & No formal education & 88.2 & 68.3 & 78.8 \\
\hline & Basic & 4.2 & 21.7 & 12.9 \\
\hline & Secondary & 5 & 7.5 & 6.3 \\
\hline & College/tertiary & 2.5 & 2.5 & 2.5 \\
\hline \multirow{4}{*}{ Household composition } & $1-4$ members & 8.4 & 20.8 & 14.6 \\
\hline & 5-8 members & 22.7 & 26.7 & 25.0 \\
\hline & 9-12 members & 20.2 & 22.5 & 21.2 \\
\hline & $>12$ members & 48.7 & 30.0 & 39.2 \\
\hline \multirow{4}{*}{ Household income from crops (GHC) } & Up to 500 & 18.5 & 35.0 & 27.1 \\
\hline & Up to 1,000 & 40.3 & 26.7 & 33.8 \\
\hline & Up to 2,000 & 31.1 & 10.8 & 20.8 \\
\hline & Above 2,000 & 10.1 & 26.7 & 18.3 \\
\hline
\end{tabular}

Cost and income are stated in Ghana Cedis (GHC); current exchange rate is approximately $\$ 1=\mathrm{GHC} 4.4$.

TABLE 2: Seasonal calendar of sweet potato production operations in Northern Ghana.

\begin{tabular}{|c|c|c|c|c|c|c|c|c|c|c|c|c|}
\hline Production operations & Jan. & Feb. & Mar. & Apr. & May & Jun. & Jul. & Aug. & Sep. & Oct. & Nov. & Dec. \\
\hline Management of conservation nurseries & +++ & +++ & +++ & +++ & & & & & & & & +++ \\
\hline Management of secondary nurseries & & & & & +++ & +++ & +++ & +++ & & & & \\
\hline Land preparation & & & & & & +++ & +++ & +++ & & & & \\
\hline Early planting & & & & & +++ & +++ & +++ & & & & & \\
\hline Late planting & & & & & & & +++ & +++ & & & & \\
\hline Field agronomic operations & & & & & & +++ & +++ & +++ & +++ & +++ & & \\
\hline Harvesting operations & & & & & & & & & +++ & +++ & +++ & \\
\hline Storage operations & +++ & & & & & & & & & & +++ & +++ \\
\hline Marketing and distribution & +++ & & & & & & & & +++ & +++ & +++ & +++ \\
\hline Processing & +++ & & & & & & & & & & +++ & +++ \\
\hline Utilization period & +++ & & & & & & & & +++ & +++ & +++ & +++ \\
\hline
\end{tabular}

after harvest. Land holding scarcity was a major challenge particularly in the Upper East Region of Ghana where the population density is high. Also there was competing interest in land use for the main staple crops (maize, millet, and sorghum). The cost of ploughing constituted the major cost component $(33.4 \%)$ in production. Other cost components were sowing/planting (6.1\%), weeding (22.9\%), fertilizer (16.2\%), seed (20.6\%), and insecticide spraying (1.6\%).

Analysis of output and revenue was conducted at two different harvest periods, early harvest (September to October) and late harvest (November to December). The average output across locations was 19 bags per hectare, approximately $1984.3 \mathrm{~kg} / \mathrm{ha}$ (Table 5). Higher price was obtained in the early harvest season compared to late harvest season. Both the gross margin profit and benefit-cost ratio analyses revealed that sweet potato production is profitable. In terms of gross margin percentage, approximately $68.1 \%$ of profit can be made at the current production cost for early season harvest compared to $60.6 \%$ gross margin for those farmers who harvest late in November to December. Similarly, the benefit to cost analysis (BCR) indicated that production was profitable at both harvest seasons with BCR of 3.2 and 2.4 for early and late harvest seasons, respectively. A report from similar study showed benefit-cost ratios of 2.5, 2.0, and 2.5 in Northern Upper West and Upper West Regions, respectively [9]. Several studies noted that it was economically feasible 
TABLE 3: Characteristics of sweet potato production operations (\% responding).

\begin{tabular}{|c|c|c|c|c|}
\hline Production operations & Description & Northern region & $\begin{array}{l}\text { Upper East } \\
\text { region }\end{array}$ & Total \\
\hline \multirow{5}{*}{ Average size of farm (ha) } & 0.5 & 69.7 & 35.0 & 52.5 \\
\hline & 1 & 18.5 & 25.0 & 21.7 \\
\hline & 2 & 10.9 & 28.3 & 19.6 \\
\hline & 3 & 0.8 & 5.8 & 3.3 \\
\hline & 4 and above & - & 5.8 & 2.9 \\
\hline \multirow{4}{*}{ Source of seed for planting } & Own seed & 36.1 & 44 & 40 \\
\hline & Recycled improved seed & 15 & 30 & 22.5 \\
\hline & Certified seed & 6 & 9 & 7.5 \\
\hline & $\begin{array}{l}\text { From MoFA, CIP, SARI, } \\
\text { or NGOs }\end{array}$ & 42.9 & 17 & 30 \\
\hline \multirow{4}{*}{$\begin{array}{l}\text { Number of years seed has been } \\
\text { recycled (years) }\end{array}$} & $1-2$ & 69.7 & 20.0 & 50.8 \\
\hline & $3-5$ & 18.5 & 30.0 & 23.3 \\
\hline & $6-10$ & 5.9 & 29.2 & 15.4 \\
\hline & $>10$ & 5.9 & 20.8 & 10.4 \\
\hline \multirow{4}{*}{$\begin{array}{l}\text { Average quantity harvested } \\
\text { (bags: } \sim 105 \mathrm{~kg} \text { ) }\end{array}$} & $1-3$ & 84.9 & 8.3 & 46.7 \\
\hline & $4-6$ & 5.0 & 20.8 & 12.9 \\
\hline & $7-10$ & 6.7 & 21.7 & 14.2 \\
\hline & $>10$ & 3.4 & 49.2 & 26.3 \\
\hline \multirow{4}{*}{$\begin{array}{l}\text { Proportion of harvested produce } \\
\text { consumed by household }\end{array}$} & Up to $25 \%$ & 41.0 & 5.0 & 22.9 \\
\hline & Up to $50 \%$ & 13.4 & 69.2 & 41.3 \\
\hline & Up to $75 \%$ & 30.1 & 21.7 & 26.3 \\
\hline & Everything is consumed & 15.1 & 4.2 & 9.6 \\
\hline \multirow{6}{*}{$\begin{array}{l}\text { Proportion of household income } \\
\text { from sweet potato production }\end{array}$} & $10 \%$ & 75.6 & 20.8 & 17.9 \\
\hline & $20 \%$ & 11.8 & 40.0 & 30.8 \\
\hline & $40 \%$ & 11.8 & 19.2 & 22.1 \\
\hline & $60 \%$ & 0.8 & 17.5 & 18.3 \\
\hline & $80 \%$ & - & 2.5 & 9.6 \\
\hline & $100 \%$ & & & 1.3 \\
\hline \multirow{4}{*}{$\begin{array}{l}\text { How long sweet potato is } \\
\text { available for consumption at } \\
\text { home (weeks) }\end{array}$} & $1-2$ & 48.7 & 14.2 & 31.7 \\
\hline & $3-4$ & 42.0 & 25.8 & 33.3 \\
\hline & $5-8$ & 8.4 & 35.6 & 21.7 \\
\hline & $9-12$ & 1.7 & 25.0 & 13.3 \\
\hline \multirow{4}{*}{$\begin{array}{l}\text { Length of storage after harvest } \\
\text { (weeks) }\end{array}$} & I do not store at all & 25.2 & 9.2 & 17.5 \\
\hline & $1-2$ & 28.6 & 9.2 & 18.8 \\
\hline & $3-4$ & 38.7 & 28.3 & 33.3 \\
\hline & $>4$ & 7.6 & 53.3 & 30.4 \\
\hline \multirow{3}{*}{ Method of storage } & Temporal shed & 27.7 & 16.7 & 22.5 \\
\hline & Underground pit & 41.1 & 31.7 & 35.8 \\
\hline & $\begin{array}{c}\text { Heap with intermittent } \\
\text { watering }\end{array}$ & 31.1 & 51.7 & 41.7 \\
\hline
\end{tabular}

Note. Full list of acronyms has been provided at the tail end of this manuscript.

to increase cost by applying fertilizer and external inputs to increase returns on investment in sweet potato production $[9,14]$. This potential has been attributed to favourable soil, climatic conditions, and production technologies for higher yields in such areas; addressing farmers' current production constraints could yield even higher returns.
3.4. Integrated Pest Management Practices. Up to $80 \%$ of growers encountered pest and disease problems in their farms but only $42.5 \%$ of them attempted some pest control measures (Table 6). The growers perceived insect damage as minor economic loss apparently due to the low grading and standardization practices in domestic trade. Farmers enumerated 
TABLE 4: Farm size and cost and revenue structure analyses of sweet potato production in Northern Ghana.

\begin{tabular}{|c|c|c|c|c|}
\hline Cost variable & Mean & Std. dev. & Min & Max \\
\hline Farm size (ha) & 0.5 & 0.3 & 0.2 & 4.0 \\
\hline Fertilizer use (kg/ha) & 49.2 & 54.3 & 0.0 & 200.0 \\
\hline Cost of ploughing & $181.4(33.4 \%)$ & 51.9 & 62.5 & 300.0 \\
\hline Cost of sowing/planting & $32.9(6.1 \%)$ & 13.6 & 9.0 & 75.0 \\
\hline Cost of seed & $111.7(20.6 \%)$ & 56.6 & 35.7 & 300.0 \\
\hline Cost of weeding & $124.4(22.9 \%)$ & 44.0 & 50.0 & 250.0 \\
\hline Cost of fertilizer & $88.0(16.2 \%)$ & 100.4 & 0.0 & 500.0 \\
\hline Cost of insecticide spraying & $4.2(1.6 \%)$ & 9.6 & 0.0 & 50.0 \\
\hline Total cost/ha & 542.5 & 121.7 & 250.0 & 925.0 \\
\hline Yield (bags) & 18.9 & 4.9 & 11.3 & 31.50 \\
\hline Yield $(\mathrm{kg}) / \mathrm{ha}$ & 1984.3 & 509.5 & 1181.3 & 3307.5 \\
\hline TR/ha (early harvest) & 1752.6 & 500.3 & 956.2 & 3142.1 \\
\hline TR/ha (late harvest) & 1375.5 & 408.5 & 731.2 & 2513.7 \\
\hline Price/bag (early harvest) & 92.5 & 7.5 & 85.0 & 100.0 \\
\hline Price/bag (late harvest) & 72.5 & 7.5 & 65.0 & 80.0 \\
\hline Price/kg (early harvest) & 0.9 & 0.1 & 0.8 & 1.0 \\
\hline Price/kg (Late harvest) & 0.7 & 0.1 & 0.6 & 0.8 \\
\hline
\end{tabular}

All cost and price items are in Ghana Cedis (GHC); current exchange rate is approximately $\$ 1=\mathrm{GHC} 4.4$.

TABLE 5: Output and revenue at early and late harvest seasons of sweet potato.

\begin{tabular}{lccc}
\hline Time of sale & Output & Early harvest & Late harvest \\
\hline Yield (bags)/ha & 18.9 & 0.0 & 0.0 \\
Yield (kg)/ha & 1984.3 & 0.0 & 0.0 \\
Price/bag & 0.0 & 92.5 & 72.5 \\
Price/kg & 0.0 & 0.9 & 0.69 \\
TR/ha & 0.0 & 1752.6 & 1375.1 \\
TVC/ha & 0.0 & 542.5 & 542.5 \\
Gross margin & 0.0 & 1210.1 & 832.6 \\
Gross margin percentage & 0.0 & 68.1 & 60.6 \\
BCR & 0.0 & 3.2 & 2.4 \\
\hline
\end{tabular}

All cost and price items are in Ghana Cedis (GHC); current exchange rate is approximately \$ 1: GHC 4.4.

TABLE 6: Integrated pest management strategies adopted by growers (\% responding).

\begin{tabular}{|c|c|c|c|c|}
\hline & Description & Northern region & Upper East region & Total \\
\hline \multirow{2}{*}{ Did you encounter pest and diseases in production? } & Yes & 75.6 & 84.2 & 80.0 \\
\hline & No & 242 & 15.8 & 20.0 \\
\hline \multirow{2}{*}{ Did you apply any pest management method last season? } & Yes & 12.6 & 72.5 & 42.5 \\
\hline & No & 87.4 & 27.5 & 57.5 \\
\hline \multirow{2}{*}{ Which method did you adopt? } & Insecticide spray & - & 87.7 & 87.7 \\
\hline & Neem or ash & 12.3 & 12.3 & 12.3 \\
\hline \multirow{8}{*}{ Type of pests/disease often encountered } & Sweet potato weevil & 36.5 & 48.0 & 42.3 \\
\hline & Millipedes & 24 & 21 & 22.3 \\
\hline & Sweet potato virus & 20 & 15 & 17.5 \\
\hline & sweet potato butterfly & 4.5 & 9.5 & 7.0 \\
\hline & Leaf feeders/hoppers & 6 & 2.5 & 4.3 \\
\hline & Rodents & 5 & 1.0 & 3.0 \\
\hline & White flies & 2 & 2.5 & 2.3 \\
\hline & Termites & 2 & 0.5 & 1.3 \\
\hline
\end{tabular}


TABLE 7: Farmers perception and ranking of critical production constraints.

\begin{tabular}{|c|c|c|c|c|}
\hline Constraints identified & Mean & Std. dev. & Mean rank & Ranking \\
\hline Access to improved seed & 3.1 & 1.6 & 6.2 & 1 \\
\hline Cost of chemical fertilizer & 3.3 & 1.4 & 6.3 & 2 \\
\hline Poor storage or short shelf-life & 3.4 & 1.7 & 6.9 & 3 \\
\hline Pests and diseases & 3.5 & 1.6 & 7.0 & 4 \\
\hline Poor soil fertility & 3.5 & 1.7 & 7.2 & 5 \\
\hline Preseason and intermittent drought & 3.6 & 1.7 & 7.7 & 6 \\
\hline Poor access to credit & 3.6 & 1.7 & 7.7 & 6 \\
\hline Low profit & 3.8 & 1.8 & 8.2 & 7 \\
\hline Poor price at harvest & 3.8 & 1.8 & 8.2 & 7 \\
\hline Vines are expensive & 4.0 & 1.3 & 8.4 & 8 \\
\hline Lack of improved varieties & 4.1 & 1.2 & 8.6 & 9 \\
\hline Drudgery production operations & 4.6 & 1.5 & 10.4 & 10 \\
\hline Perceived as food for poor households & 4.7 & 1.3 & 10.5 & 11 \\
\hline Poor market for produce & 4.8 & 1.3 & 10.8 & 12 \\
\hline Difficult to process into preservable forms & 4.8 & 1.2 & 11.0 & 13 \\
\hline Access to farm labour & 4.8 & 1.2 & 11.0 & 13 \\
\hline
\end{tabular}

Note. Rank 1 is the most constraining factor and in similar order. Chi Square: 498.9, $P_{<0.05}: 0.000$, and Kendall's $(W):(0.139)$.

the most economic pests and diseases as sweet potato weevil (Cylas spp.) (42.3\%), millipedes (22.3\%), sweet potato virus disease $(17.8 \%)$, and sweet potato butterfly (Acraea acerata) (7\%). Though several leaf feeding and mining insects were observed, farmers perceived them as minor and did not conduct any management strategy to mitigate their damage.

Insect pests reported in this study were similar to those recorded by Shonga et al. and Tanzubil [21, 22]. Growers often perceive insect pests as a minor challenge in most root and tuber crops production. In spite of the high prevalence of insect pests in yam (Dioscorea spp.) production, for instance, farmers (97\%) did not practice any type of pest control because they lacked the knowledge of appropriate control methods [23]. A similar study in Frafra potato (Solenostemon rotundifolius Poir.) production [24] found that farmers did not practice pest control measures due to lack of technical know-how. However, controlling both foliar and soil pests increased tuber yield by 23 to $64 \%$ over the control plots. Incidence of Cylas spp. was up to $90 \%$ of farms surveyed causing $30.8 \%$ and $41.4 \%$ damage to vines and roots, respectively, in the Upper East of Ghana [22]. In Kenya, $63.8 \%$ of the farmers perceived Cylas spp. as the most important followed by sweet potato butterfly $(27.6 \%)$, leaf miner $(8.6 \%)$, and vine borers (8.6\%) [21].

3.5. Production Constraints. Five most prioritized constraints were access to seed, cost of chemical fertilizers, short shelflife, field pests and diseases, and declining soil fertility (Table 7). By classifying these constraints into technical, production, socioeconomic, and sociocultural food habits, the most prioritized technical constraints were pests and diseases, short shelf-life and declining soil fertility. Sustainable interventions should be identified to increase the number of seed multiplication gardens to generate enough certified seed to meet the demand gap. Somehow, these constraints are similar in other studies in Ethiopia [3], Ghana [9], Tanzania [12], and Kenya [20]. Lack of improved seed was mentioned as the major limiting factor to the expansion of sweet potato farms in an earlier study in Northern and Upper West Region [9]. Some other studies in Ghana identified lack of good markets and high perishability to be limiting factors to production $[9,11]$. The availability of good output markets will motivate growers to expand on production. Low yields due to the use of local landraces which are also susceptible to diseases and insect pests have been reported in Tanzania [12]. Access to quality seed especially during the critical period of planting was a critical problem in Kenya [20]. Although sweet potato has a yield potential above 50 to 60 t/ha in Ethiopian conditions, yield obtained from farmer's field is about 6 to $8 \mathrm{t} / \mathrm{ha}$ [3]. This variation has been attributed to biotic and abiotic stresses, lack of improved cultivars, and weak attitude of farmers toward sweet potato technologies as well as lack set of a packaged agronomic recommendations.

3.6. Utilization Options. Figure 1 summarizes some of the utilization options of sweet potato. Although the leaves are edible, the starchy storage roots were the most important product. The roots were mostly boiled, fried, roasted, or baked for their rich source of dietary energy and quite recently for their beta-carotene and vitamin $\mathrm{C}$. White-fleshed cultivars have already been contributing to household food security, but orange-fleshed cultivars now have the potential to alleviate vitamin A deficiency when incorporated into familiar foods. Industrial uses such as the production of starch, alcohol, and partial flour substitute are further utilization options that can be explored in Ghana. Another option is sweet potato fodder and silage for livestock feeding, which has high protein and digestibility values $[7,8]$. 


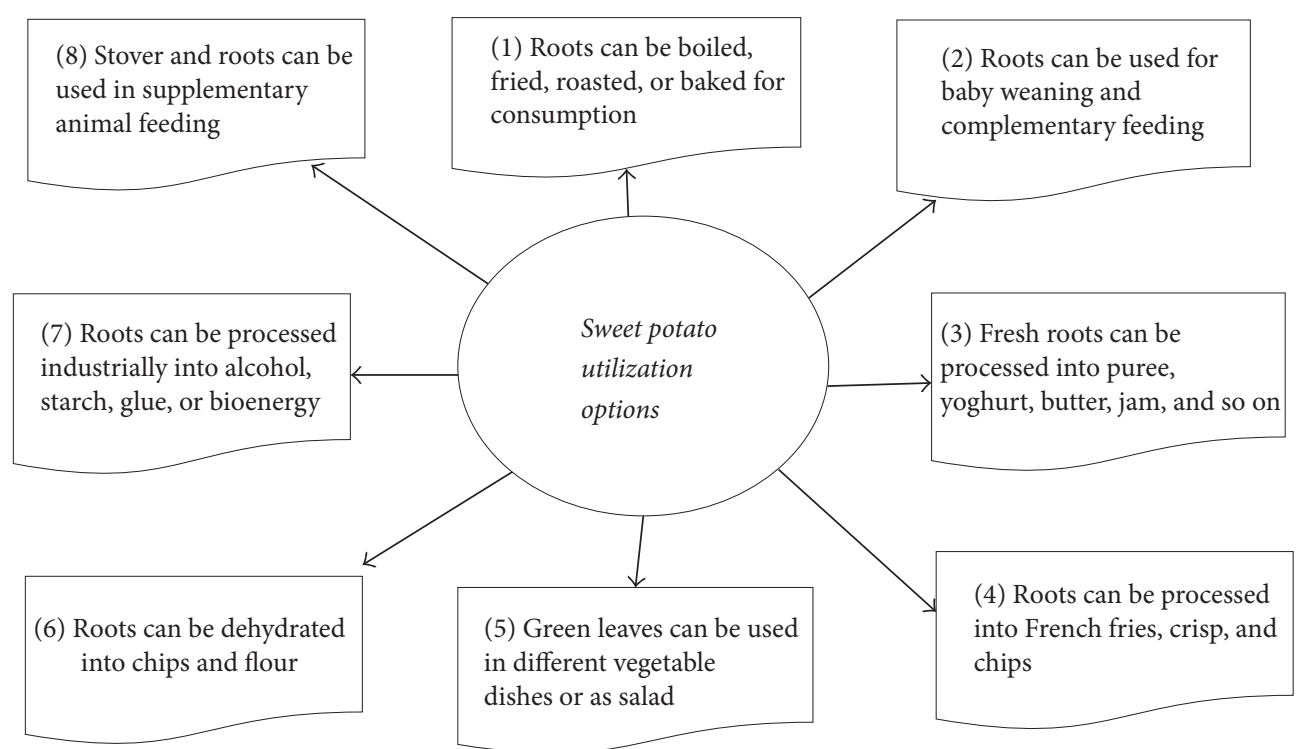

FIGURE 1: Options for utilizing various parts of sweet potato.

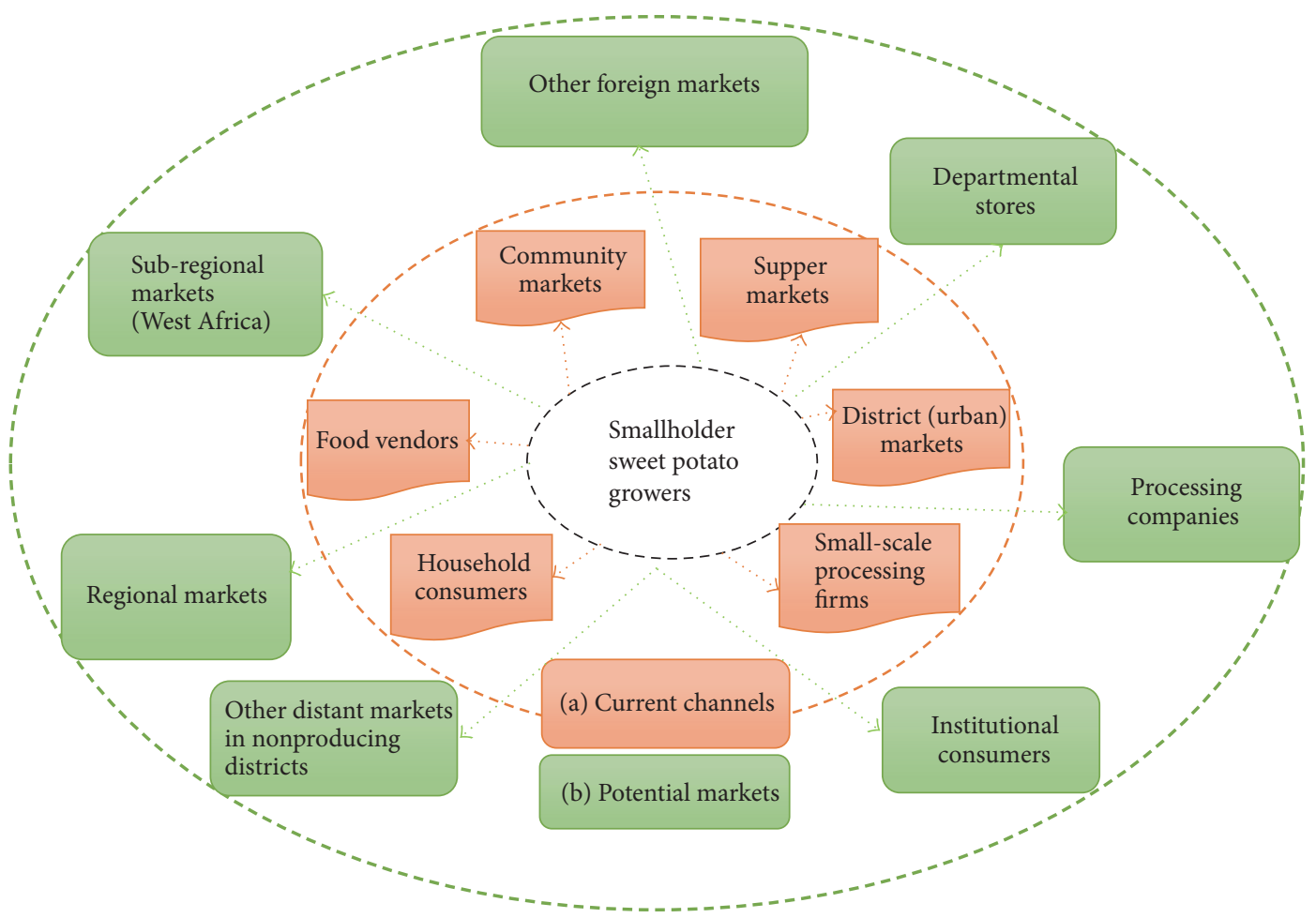

FIGURE 2: Market channels for fresh sweet potato root in Ghana.

3.7. Markets and Marketing Channels. The current market participants consisted of farmers, traders, commission agents, processors, and consumers. The participants were mainly smallholders operating privately on individual basis. The industry was largely a fresh produce market, targeting food vendors, processors, and direct selling to wholesalers, retailers, and household consumers (Figure 2). Middlemen usually transported the produce by using hired trucks to neighbouring districts or urban markets. There was little regulation and standardization, and prices were determined by market forces of demand and supply. In the Upper East Region, fresh roots were being exported to neighbouring countries such as Togo and Burkina Faso through middlemen. The choice of these markets was due to ready markets but not higher prices. From the key informant interviews, the concerns of traders and processors were similar. The 
TABLE 8: SWOT analysis of the sweet potato value chain in Northern Ghana.

\begin{tabular}{ll}
\hline Strengths & Weaknesses \\
\hline (i) Low external inputs requirement & (i) Low price at harvest \\
(ii) Many producers are available & (ii) Too sweet to adults \\
(iii) Ready available markets & (iii) Not consumed as a main meal \\
(iv) Availability of improved cultivars & (iv) Highly perishable roots \\
(v) Improved technologies available & (v) Poor grading and standardization \\
(vi) Institutional technical capacity available & (vi) Improved storage facilities not available \\
(vii) Favourable policy environment & (vii) Lack of improved preservation methods \\
(viii) Favourable production ecologies & (viii) Insufficient access to vines at planting \\
(ix) Enormous health benefits & (ix) Little women involvement in production \\
\hline Opportunities & Threats \\
\hline (i) Preferred by children & (i) Field pests and diseases \\
(ii) Demand for orange-fleshed cultivars & (ii) Short shelf-life \\
(iii) High cost-benefit ratio to farmers & (iii) Seasonal glut leading to low price \\
(iv) Available land resources & (iv) Poor transport/handling facilities \\
(v) Many potential markets & (v) Low financial support to growers \\
(vi) For complementary animal feed & (vi) Low awareness on health benefits \\
(vii) Many diversified uses & (vii) Poor consumer perception \\
(viii) Many processing options & (viii) Poor quality standardization \\
(ix) Insatiable export markets & (ix) Availability of close substitutes (potato and yam) \\
(x) Favourable policy and donor goodwill & (x) Competing interest for land use for cereals \\
\hline
\end{tabular}

main issues related to the narrow period of harvesting and lack of storage methods to extend shelf-life of fresh produce, resulting in glut and low prices.

The current sweet potato market is reminiscent of most dysfunctional markets, where the smallholder participants such as farmers, traders, processors, and consumers tend to have different perspectives of the market, which is shaped by their experiences and profit motives. The market actors occasionally view problems in terms of blame and mistrust, rather than framing them as blockages and opportunities that can be solved collaboratively $[17,25]$. The value chain approach is promulgated to change this perception by mobilizing the actors to develop broader understanding of their responsibilities and potential benefits thereof. Through this process, smallholders and marginalized actors who may be excluded from business opportunities can access better markets under much equitable conditions. Only investments to increase production volumes may not solely benefit farmers due to price volatility associated with perishability agricultural commodities such as sweet potato. Research evidence suggests that value chain approaches have the propensity to encourage governments and investors, including farmers, to expand agroindustrial activities and linkages to export markets as a means of increasing local food production, employment, business development, and international trade $[25,26]$. This can lead to competition among producers to meet export market demands in terms of cost, quality, and delivery times. By this approach, policies, regulations, support services, tax and trade instruments, and their associated actors and institutions can develop to become intrinsic parts of such "value chains." Whereas consumers and urban populations could benefit from lower prices resulting from increased production, the smallholder farmers may not. The primary actors such as seed producers, farmers, traders, and processors need to form welfare associations to operate with a "win-win motive."

3.8. SWOT Analysis. Table 8 summarizes the strengths, weakness, opportunities, and threats (SWOT) analysis of SPVC collated from different multistakeholder platforms. The salient opportunities include favourable production ecologies and processing options as well as insatiable local and international markets for both fresh and processed products. The focus group discussions and key informant interviews showed that commercialization drive for sweet potato has positive outlook due to increasing urbanization and changing consumer behaviour for healthy foods. The value chain upgrading window (Figure 3) identifies other potential markets and opportunities of collaboration and priority technologies for research and extension considerations. Commercialization strategy at national level should consider public awareness, mobilizing many institutional consumers, and processing into preservable products as well as lobbying for sweet potato to be included in complementary feeding programmes such as schools, hospitals, and prison menus.

3.9. Progress in Variety Development. For two decades now, a stalwart in developing the root and tuber crops in Ghana has been the Root and Tuber Improvement and Marketing Programme (RTIMP) and partners. The major partners have been the Government of Ghana via MoFA, International 


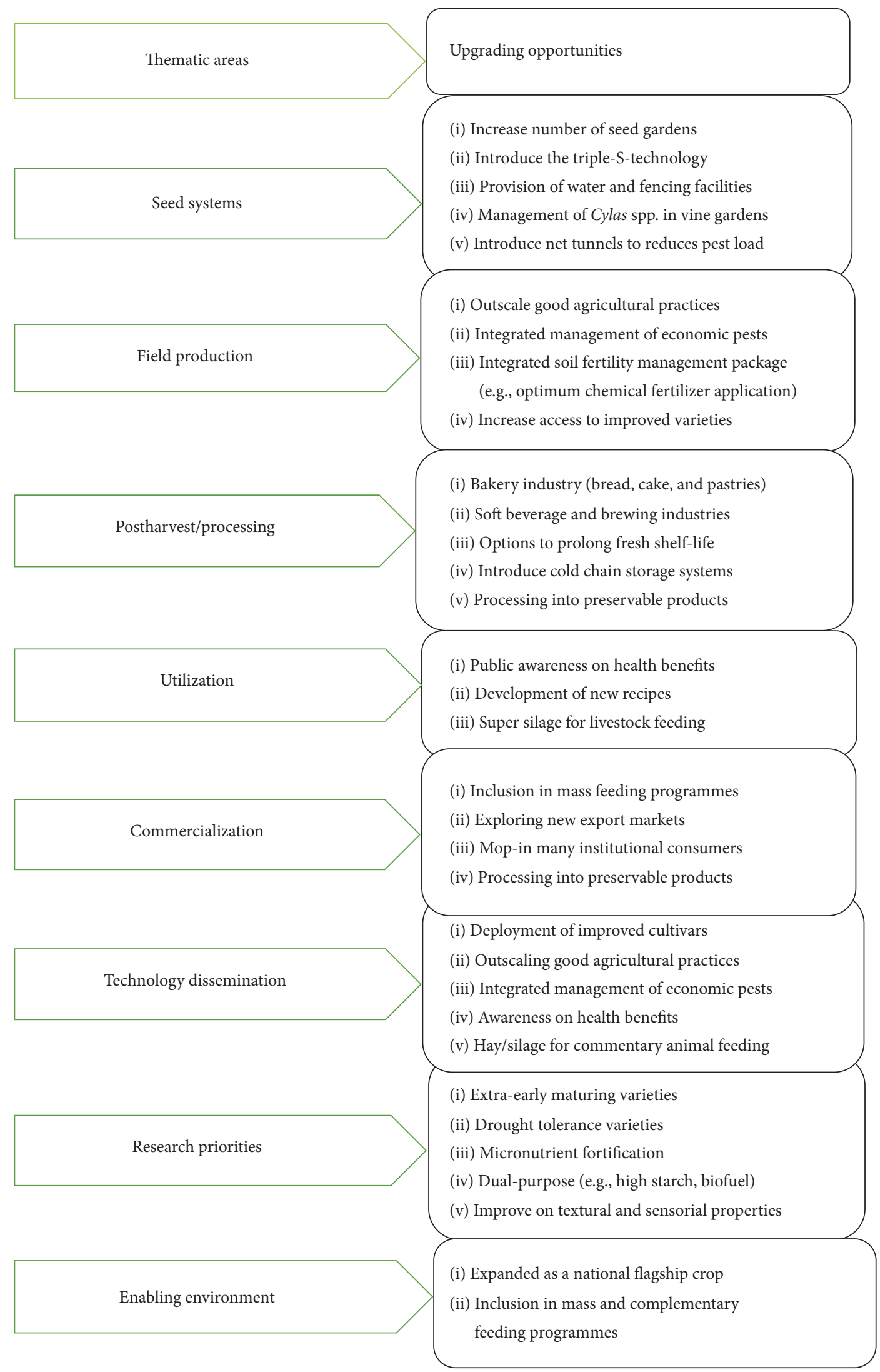

FIGURE 3: Value chain upgrading opportunities in Ghana. 
TABLE 9: Description of some improved cultivars of sweet potato in Ghana.

\begin{tabular}{|c|c|c|c|c|c|c|c|}
\hline Name of variety & Year of release & Original name & Origin & Skin colour & Flesh colour & $\begin{array}{c}\text { Dry matter } \\
\text { content } \\
(\%)\end{array}$ & $\begin{array}{l}\text { Yield potential } \\
\qquad(\mathrm{t} / \mathrm{ha})\end{array}$ \\
\hline Okumkom & 1998 & TIS 8277 & IITA & Pink & Cream & 30 & 20 \\
\hline Sauti & 1998 & Tanzania & Malawi & Cream & Dark yellow & 35 & 19 \\
\hline Faara & 1998 & TIS 3017 & IITA & Dark purple & Pale yellow & 34 & 22 \\
\hline Santom pona & 1998 & TIS $88 / 0320$ & IITA & Copper & Yellow & 32 & 17 \\
\hline Tech-Santom & 2003 & TIB 2 & IITA & Yellow & Light yellow & 31 & 20 \\
\hline CSIR-CRI Hi starch & 2005 & Hi-starch & Japan & Brown & Cream & 40 & 18 \\
\hline CSIR-CRI Ogyefo & 2005 & Mugande & Rwanda via CIP & Red & White & 34 & 20 \\
\hline CSIR-CRI Otoo & 2005 & Mogamba & Burundi via CIP & Cream & Light orange & 33 & 23 \\
\hline CSIR-CRI Apumuden & 2005 & Kamala & Bangladesh via CIP & Copper & Orange & 22 & 35 \\
\hline CSIR-CRI Patron & 2012 & Mohc & Burundi via CIP & Dark yellow & Dark yellow & 34 & 20 \\
\hline CSIR-CRI Bohye & 2012 & 199062.1 & CIP-Peru & Purple & Pale orange & 31 & 22 \\
\hline CSIR-CRI Ligri & 2012 & Cemsa 74-228 & CIP-Kenya & Cream & Pale yellow & 35 & 22 \\
\hline CSIR-CRI Dadanyuie & 2012 & Kemb 37 & CIP-Kenya & Dark purple & White & 35 & 18 \\
\hline
\end{tabular}

Note. This information was collated from different secondary sources with varying degrees of accuracy.

Fund for Agricultural Development (IFAD), the International Potato Center (CIP), and International Institute of Tropical Agriculture (IITA) in collaboration with the National Agricultural Research Systems (NARS). Hitherto, farmers were cultivating low yielding white-fleshed cultivars which have low or no beta-carotene. These partnerships have recorded great successes particularly at introducing orange-fleshed cultivars with resistance to the sweet potato virus disease. Some of the varieties released over this period are described in Table 9.

Over this period, research interest and consumer perception, preference, and utilization have evolved to several dimensions. The influence of colour, dry matter, and texture in particular, alongside nutritional benefits, has been the subject of most discussions. Undoubtedly, the decision to adopt a new cultivar is complexly related to field and yield performance as well as market and consumer taste acceptability. Earlier attempts to introduce orange-fleshed cultivars from Taiwan, Mainland China, and IITA failed because of their low dry matter content and squash-like flavour [27]. However, consumer acceptance has improved tremendously due to several research and promotions to address these weaknesses in countries such as Mozambique [28], Kenya [29], Ghana [30], and Tanzania [31]. Although consumers preferred orange- to white-fleshed cultivars, their low dry matter content was a limiting quality attribute [28]. In Ghana, cultivars with descriptors such as starchiness and stickiness, less dense texture requiring little chewing with strong flavour, and good mouth-feel were appealing to consumers [30]. Quite recently, the need to reduce the sweetness of existing and/or new genotypes has been suggested [16].

3.10. Current Partnerships. In most agrovalue chains, the national economic landscape, policies, laws, regulations, standards, and institutional elements such as research and technology innovations, human resource development, and other support services form the environment in which all activities operate $[25,26]$. Table 10 identifies some current and potential actors as well as their functions and interrelationships in the SPVC in Ghana. Currently, a couple of strategies are being implemented by NARS and their partners including introduction of improved cultivars and outscaling of improved production and postharvest practices. Some partners are working with food processors and bakers to formulate flours, bread, purees, beverages, and weaning foods using different cultivars. Attempts are being made to promote the inclusion of sweet potato in traditional recipes, school feeding programme menu, and complementary feeding for pregnant and lactating women. Some local bakers are now using sweet potato puree to make yoghurt and bread.

Projects such as the Sweet Potato Action for Security and Health in Africa (SASHA) and the West African Agricultural Productivity Project (WAAPP2A) in collaboration with CIP and NARS of Ghana are engaged in novel breeding programmes as well as participatory variety development programmes. Ghana is the lead country for root crop research under the WAAPP2A, with the CSIR-Crop Research Institute being the designated National Centre of Specialization. These partnerships have established a strong foundation for collaborative breeding at multilocations of Ghana, with close links to breeding programmes in Burkina Faso and Nigeria. Ongoing-breeding work at the clonal and advanced stages for stable yield, drought tolerance, and other multitraits are in progress. In Northern Ghana, CSIR-SARI, CIP, UDS, and some NGOs are important partners in the dissemination of technologies. The Alliance for a Green Revolution in Africa (AGRA) supported the West Africa Centre for Crop Improvement (WACCI) at the University of Ghana, Legon, to provide technical backstopping via research and training of doctorial students by employing novel breeding approaches in sweet potato improvement. 
TABLE 10: Multistakeholder mapping of actors and identification of their roles in the SPVC.

\begin{tabular}{|c|c|c|}
\hline $\begin{array}{l}\text { Step I } \\
\text { Critical functions }\end{array}$ & $\begin{array}{l}\text { Step II } \\
\text { Current/potential actors }\end{array}$ & $\begin{array}{l}\text { Step III } \\
\text { Specific roles }\end{array}$ \\
\hline Input supply & Agroinput dealers at district and regional levels & $\begin{array}{l}\text { Increase access to production inputs, } \\
\text { processing implements, machines. }\end{array}$ \\
\hline Seed access & $\begin{array}{l}\text { Vine multipliers, MoFA, CSIR-CRI, CSIR-SARI, CIP, } \\
\text { NGOs }\end{array}$ & $\begin{array}{l}\text { (i) Ensure adequate supply of vines of } \\
\text { improved cultivars to growers. } \\
\text { (ii) Provide facilities in increase the number of vine } \\
\text { multiplication gardens. }\end{array}$ \\
\hline Production & $\begin{array}{l}\text { Farmers, FBOs, WIAD-MoFA, MoFA, } \\
\text { RTIMP-MoFA, CSIR-CRI, CSIR-SARI, CIP, NGOs, } \\
\text { donor agencies }\end{array}$ & $\begin{array}{l}\text { (i) Increase production to satisfy the rapidly } \\
\text { expanding markets and consumer demand. } \\
\text { (ii) Enhance access to improved production } \\
\text { technologies. }\end{array}$ \\
\hline $\begin{array}{l}\text { Processing and } \\
\text { value addition }\end{array}$ & $\begin{array}{l}\text { Processors, WIAD-MoFA, MoFA, CSIR (CRI, SARI, } \\
\text { FRI), CIP, NGOs, Faculties of Agric., Food and } \\
\text { Nutrition Department of universities and } \\
\text { Polytechnics }\end{array}$ & $\begin{array}{l}\text { (i) Processing into stable preservable forms. } \\
\text { (ii) Development of new recipes. } \\
\text { (iii) Training on new recipes and utilization. } \\
\text { (iv) Research into health and nutritional benefits. }\end{array}$ \\
\hline $\begin{array}{l}\text { Extension and } \\
\text { technology } \\
\text { dissemination }\end{array}$ & $\begin{array}{l}\text { MoFA, RTIMP-MoFA, CSIR (CRI, SARI, FRI), CIP, } \\
\text { NGOs, Community Radio Stations }\end{array}$ & $\begin{array}{l}\text { (i) Increase access to improved production } \\
\text { technologies. } \\
\text { (ii) Development of improved preservation and } \\
\text { storage methods. }\end{array}$ \\
\hline $\begin{array}{l}\text { Research and } \\
\text { development }\end{array}$ & $\begin{array}{l}\text { CSIR (CRI, SARI, FRI), CGIAR (CIP, IITA), } \\
\text { Faculties of Agric., Food and Nutrition of } \\
\text { universities and Polytechnics, RTIMP-MoFA, } \\
\text { Community Radio Stations }\end{array}$ & $\begin{array}{l}\text { (i) Increase access to improved production } \\
\text { technologies. } \\
\text { (ii) Development of new recipes. } \\
\text { (iii) Development of improved preservation and } \\
\text { storage methods. }\end{array}$ \\
\hline $\begin{array}{l}\text { Commercialization } \\
\text { and utilization }\end{array}$ & $\begin{array}{l}\text { MoFA, CSIR (CRI, SARI, FRI), CIP, NGOs, } \\
\text { WIAD-MoFA, RTIMP-MoFA, GHS, MoTI, GEPC, } \\
\text { Community Radio Stations }\end{array}$ & $\begin{array}{l}\text { (i) Sensitization on health benefits. } \\
\text { (ii) Explore and promote export to foreign markets. } \\
\text { (iii) Development and promotion of new recipes. }\end{array}$ \\
\hline $\begin{array}{l}\text { Marketing and } \\
\text { distribution }\end{array}$ & $\begin{array}{l}\text { Traders, transport unions, departmental stores, CSIR } \\
\text { (CRI, SARI, FRI), CIP, NGOs, WIAD-MoFA, } \\
\text { RTIMP-MoFA, MoTI, GEPC, Community Radio } \\
\text { Stations }\end{array}$ & $\begin{array}{l}\text { (i) Expand domestic distribution to new areas. } \\
\text { (ii) Target many institutional consumers. } \\
\text { (iii) Explore and promote export to foreign markets. }\end{array}$ \\
\hline $\begin{array}{l}\text { Resource } \\
\text { mobilization }\end{array}$ & $\begin{array}{l}\text { Donor agencies such as USAID, AGRA, WAAPP, } \\
\text { IFAD, RTIMP-MoFA, CIDA, UNICEF }\end{array}$ & $\begin{array}{l}\text { Fund mobilization and strengthening the } \\
\text { technical and resource capacities of partners, } \\
\text { national agriculture research, extension } \\
\text { systems. }\end{array}$ \\
\hline $\begin{array}{l}\text { Other } \\
\text { collaborators }\end{array}$ & $\begin{array}{l}\text { NGOs (CRS, WV, ACDEP, CDP, IDE, UNICEF), } \\
\text { Tuskegee Univ., Pennsylvania State Univ., Hellen } \\
\text { Keller Int. Commercial banks and Microfinance } \\
\text { Institutions }\end{array}$ & $\begin{array}{l}\text { (i) Fund mobilization and strengthening the } \\
\text { technical and resource capacities of partners, } \\
\text { national agriculture research, extension } \\
\text { systems. } \\
\text { (ii) Sensitization on health benefits. } \\
\text { (iii) Development and promotion of new recipes. }\end{array}$ \\
\hline $\begin{array}{l}\text { Regulation and } \\
\text { quality assurance } \\
\text { management }\end{array}$ & GSA, FDA, MoFA-PPRS, GEPC & $\begin{array}{l}\text { (i) Regulation and compliance to quality } \\
\text { assurance systems. } \\
\text { (ii) Food safety, inspection, monitoring. } \\
\text { (iii) Phytosanitary issues and management. }\end{array}$ \\
\hline
\end{tabular}

Note. Full list of acronyms has been provided at the tail end of this manuscript.

\section{Conclusion}

Sweet potato production has immense potential to improve household food security, income, and nutrition in food deficit regions such as Northern Ghana. Like many root and tubers, the crop has greater ability to produce dietary energy per hectare compared to other commodities and produce satisfactory yields under adverse climate and soil conditions. Both the gross profit margin and benefit-cost ratio analyses revealed that sweet potato production was profitable at gross margin percentages of 68.1 and $60.6 \%$, and benefitcost ratios of 3.2 and 2.4 for early and late harvest seasons, respectively. The institutional actors need to link the primary actors to synergistically operate with collective profit motive. Such linkages could contribute to the dissemination of technologies to the target groups and facilitate scaling-out of promising technologies to end-users. However, proactive 
steps should be taken to address the most prioritized production constraints such as access to seed, cost of chemical fertilizer, short shelf-life, field pests and diseases, and declining soil fertility. An avalanche of opportunities to propel the SPVC have been identified in Figure 3, from which actors could explore the advantages or minimize their risk thereof. In spite of the current consumption trend and consumer perception, commercialization drive for sweet potato has prospects due to changing consumer behaviour for nutritious foods, such as the orange-fleshed cultivars. Due to the high intensive livestock production in the Bawku environs, the use of super silage, prepared through fermenting vines, and storage roots (of noncommercial root grade), which are chopped and preserved hermitically, can be promoted by the Department of Agriculture for complementary feeding of livestock in the dry season.

\section{Abbreviations}

ACDEP: Association of Church Development Projects

AGRA: The Alliance for a Green Revolution in Africa

CDP: Catholic Diocesan Project

CRI: Crop Research Institute

CIP: The International Sweet Potato Center

CSIR: Council for Scientific and Industrial Research

FBOs: Farmer Based Organizations

FDA: $\quad$ Food and Drugs Authority

FRI: $\quad$ Food Research Institute

GEPC: Ghana Export Promotion Council

GSA: Ghana Standards Authority

IITA: International Institute for Tropical Agriculture

MoFA: Ministry of Food and Agriculture

MoTI: Ministry of Trade and Industry

NARS: National Agric. Research Systems

NGOs: Nongovernmental organizations

OFSP: Orange-fleshed sweet potato

PPRS: $\quad$ Plant Protection and Regulatory Services

SARI: Savanna Agricultural Research Institute

SWOT: Strengths, weaknesses, opportunities, and threats

SPVC: $\quad$ Sweet potato value chain

UNICEF: The United Nations Children Fund

WIAD: Women in Agriculture Development

WV: World Vision International.

\section{Disclosure}

The authors take full responsibility for any errors.

\section{Conflicts of Interest}

The authors declare that there are no conflicts of interest in relation to the publication of this research paper.

\section{Acknowledgments}

The authors are grateful to the participating farmers, traders, processors, and other groups that provided information during this study. The authors acknowledge the Academic
Staff of the Horticultural Science Department of the Kwame Nkrumah University of Science and Technology, Ghana, for critiquing earlier draft of this work.

\section{References}

[1] Food and Agriculture Organization of the United Nations (FAO), Food and Agriculture Organization Statistical Databases (FAOSTAT), 2015. http://faostat3.fao.org/browse/Q/QC/E.

[2] A. Elameen, S. Fjellheim, A. Larsen et al., "Analysis of genetic diversity in a sweet potato (Ipomoea batatas L.) germplasm collection from Tanzania as revealed by AFLP," Genetic Resources and Crop Evolution, vol. 55, no. 3, pp. 397-408, 2008.

[3] D. Markos and G. Loha, "Sweet potato agronomy research in Ethiopia: summary of past findings and future research directions," Agriculture and Food Sciences Research, vol. 3, no. 1, pp. 1-11, 2016.

[4] I. Chagonda, R. F. Mapfeka, and T. Chitata, "Effect of tillage systems and vine orientation on yield of sweet potato (Ipomoea batatas L.)," American Journal of Plant Sciences, vol. 5, no. 21, pp. 3159-3165, 2014.

[5] P. J. van Jaarsveld, M. Faber, S. A. Tanumihardjo et al., “ $\beta$ carotene-rich orange-fleshed sweet potato improves the vitamin A status of primary school children assessed with the modifiedrelative-dose- response test, 1-3," American Journal of Clinical Nutrition, vol. 81, no. 5, pp. 1080-1087, 2005.

[6] J. W. Low, M. Arimond, N. Osman, B. Cunguara, F. Zano, and D. Tschirley, "A food-based approach introducing orangefleshed sweet potatoes increased vitamin A intake and serum retinol concentrations in young children in rural Mozambique," Journal of Nutrition, vol. 137, no. 5, pp. 1320-1327, 2007.

[7] A. Larbi, I. Etela, H. N. Nwokocha et al., "Fodder and tuber yields, and fodder quality of sweet potato cultivars at different maturity stages in the West African humid forest and savanna zones," Animal Feed Science and Technology, vol. 135, no. 1-2, pp. 126-138, 2007.

[8] I. Etela and G. A. Kalio, "Yields components and 48-h rumen dry matter degradation of three sweet potato varieties in Ndama steers as influenced by date of harvesting," Journal of Agriculture and Social Research, vol. 11, no. 2, pp. 15-21, 2011.

[9] J. K. Bidzakin, K. Acheremu, and E. Carey, "Needs assessment of sweet potato production in northern Ghana: implications for research and extension efforts," ARPN Journal of Agriculture and Biological Science, vol. 9, no. 9, pp. 315-319, 2014.

[10] SRID, Statistics, Research and Information Division of the Ministry of Food and Agriculture, Ghana, 2013.

[11] P. E. Abidin, J. Kazembe, R. A. Atuna et al., "Sand storage, extending the shelf-life of fresh sweetpotato roots for home consumption and market sales," Journal of Food Science and Engineering, vol. 6, pp. 227-236, 2016.

[12] H. Muyinza, H. L. Talwana, R. O. M. Mwanga, and P. C. Stevenson, "Sweetpotato weevil (cylas spp.) resistance in African sweetpotato germplasm," International Journal of Pest Management, vol. 58, no. 1, pp. 73-81, 2012.

[13] J. S. Okonya and J. Kroschel, "Pest status of Acraea acerata Hew. and Cylas spp. in sweetpotato (Ipomoea batatas (L.) Lam.) and incidence of natural enemies in the Lake Albert Crescent agro-ecological zone of Uganda," International Journal of Insect Science, vol. 5, pp. 41-46, 2013.

[14] E. N. K. Sowley, M. Neindow, and A. H. Abubakari, "Effect of poultry manure and NPK on yield and storability of orange-and 
white-fleshed sweet potato (Ipomoea batatas L. Lam)," ISABBJournal of Food and Agriculture Science, vol. 5, no. 1, pp. 1-6, 2015.

[15] E. Mutandwa and C. T. Gadzirayi, "Comparative assessment of indigenous methods of sweet potato preservation among smallholder farmers: case of grass, ash and soil based approaches in Zimbabwe," African Studies Quarterly, vol. 9, no. 3, pp. 85-98, 2007.

[16] E. Baafi, J. Manu-Aduening, E. E. Carey, K. Ofori, E. T. Blay, and V. E. Gracen, "Constraints and breeding priorities for increased sweetpotato utilization in Ghana," Sustainable Agriculture Research, vol. 4, no. 4, p. 1, 2015.

[17] G. Pathania-Jain, "Global parents, local partners: a value-chain analysis of collaborative strategies of media firms in India," Journal of Media Economics, vol. 14, no. 3, pp. 169-187, 2001.

[18] P. K. Nkegbe, B. M. Abu, and H. Issahaku, "Food security in the savannah accelerated development authority zone of Ghana: an ordered probit with household hunger scale approach," Agriculture and Food Security, vol. 6, no. 1, article no. 35, 2017.

[19] P. Legendre, Coefficient of concordance. pp. 164-169 in: Encyclopedia of Research Design, Vol. 1. N. J. Salkind, ed. SAGE Publications, Inc., Los Angeles. 1776 pp. 2010.

[20] J. G. Wangombe and M. P. van Dijk, "Low potato yields in Kenya: do conventional input innovations account for the yields disparity," Agriculture and Food Security, vol. 2, no. 1, article no. 14, 2013.

[21] E. Shonga, M. Gemu, T. Tadesse, and E. Urage, "Review of entomological research on sweet potato in Ethiopia," Discourse Journal Agriculture and Food Science, vol. 1, no. 5, pp. 83-92, 2013.

[22] P. B. Tanzubil, "Insect pests of sweet potato in the Sudan savanna zone of Ghana," Journal of Entomology and Zoology Studies, vol. 3, no. 2, pp. 124-126, 2015.

[23] S. K. Asante, G. W. K. Mensah, and E. Wahaga, "Farmers knowledge and perception of insect pests of yam (Dioscorea spp.) and their indigenous control practices in the northern Ghana," Ghana Journal of Agricultural Science, vol. 40, no. 2, pp. 185-192, 2007.

[24] P. B. Tanzubil, A. Alem, and M. Zakariah, "Agronomic performance and pests of frafra potato (Solenostemon rotendifolius) in the Sudan savannah of Ghana," Tropical Science, vol. 45, no. 1, pp. 10-13, 2005.

[25] UNIDO, Agro-value chain analysis and development: The UNIDO Approach, United Nations Industrial Development Organization Staff Working papper. Vienna. pp. 1-8, 2009.

[26] E. M. Nangole, D. Mithöfer, and S. Franzel, "Review of guidelines and manuals for value chain analysis for agricultural and forest products," ICRAF Occasional Paper No. 17. Nairobi: World Agroforestry Centre, 2011.

[27] K. Tomlins, E. Rwiza, A. Nyango et al., "The use of sensory evaluation and consumer preference for the selection of sweetpotato cultivars in East Africa," Journal of the Science of Food and Agriculture, vol. 84, no. 8, pp. 791-799, 2004.

[28] A. T. A. Naico and J. L. Lusk, "The value of a nutritionally enhanced staple crop: results from a choice experiment conducted with orange-fleshed sweet potatoes in Mozambique," Journal of African Economies, vol. 19, no. 4, Article ID ejq007, pp. 536-558, 2010.

[29] J. K. Kwach, G. O. Odhiambo, M. M. Dida, and S. T. Gichuki, "Participatory consumer evaluation of twelve sweetpotato varieties in Kenya," African Journal of Biotechnology, vol. 9, no. 11, pp. 1600-1609, 2010.
[30] I. Sugri, S. K. Nutsugah, A. N. Wiredu, P. N. T. Johnson, and D. Aduguba, "Kendall's concordance analysis of sensory descriptors influencing consumer preference for sweet potatoes in Ghana," American Journal of Food Technology, vol. 7, no. 3, pp. 142-150, 2012.

[31] K. Tomlins, G. Ndunguru, K. Stambul et al., "Sensory evaluation and consumer acceptability of pale-fleshed and orange-fleshed sweetpotato by school children and mothers with preschool children," Journal of the Science of Food and Agriculture, vol. 87, no. 13, pp. 2436-2446, 2007. 


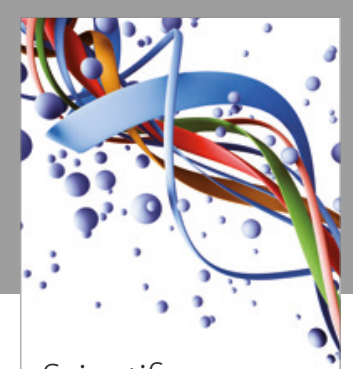

Scientifica
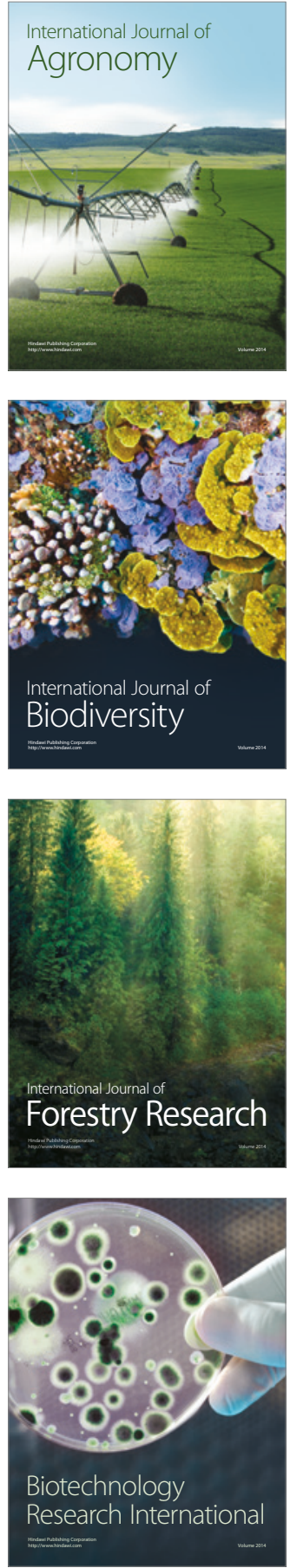
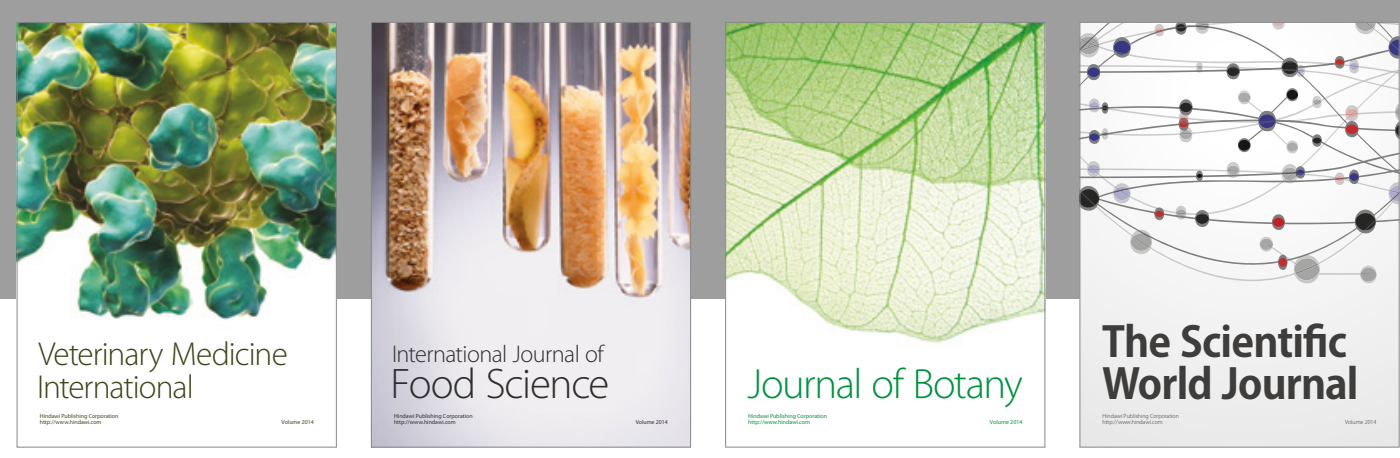

The Scientific

\section{World Journal}

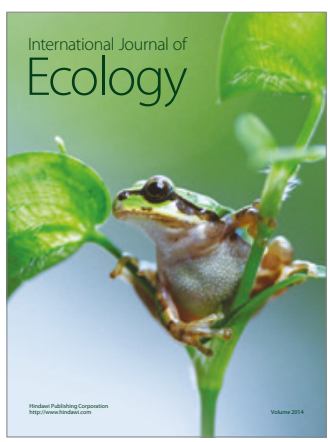

\section{Hindawi}

Submit your manuscripts at

https://www.hindawi.com
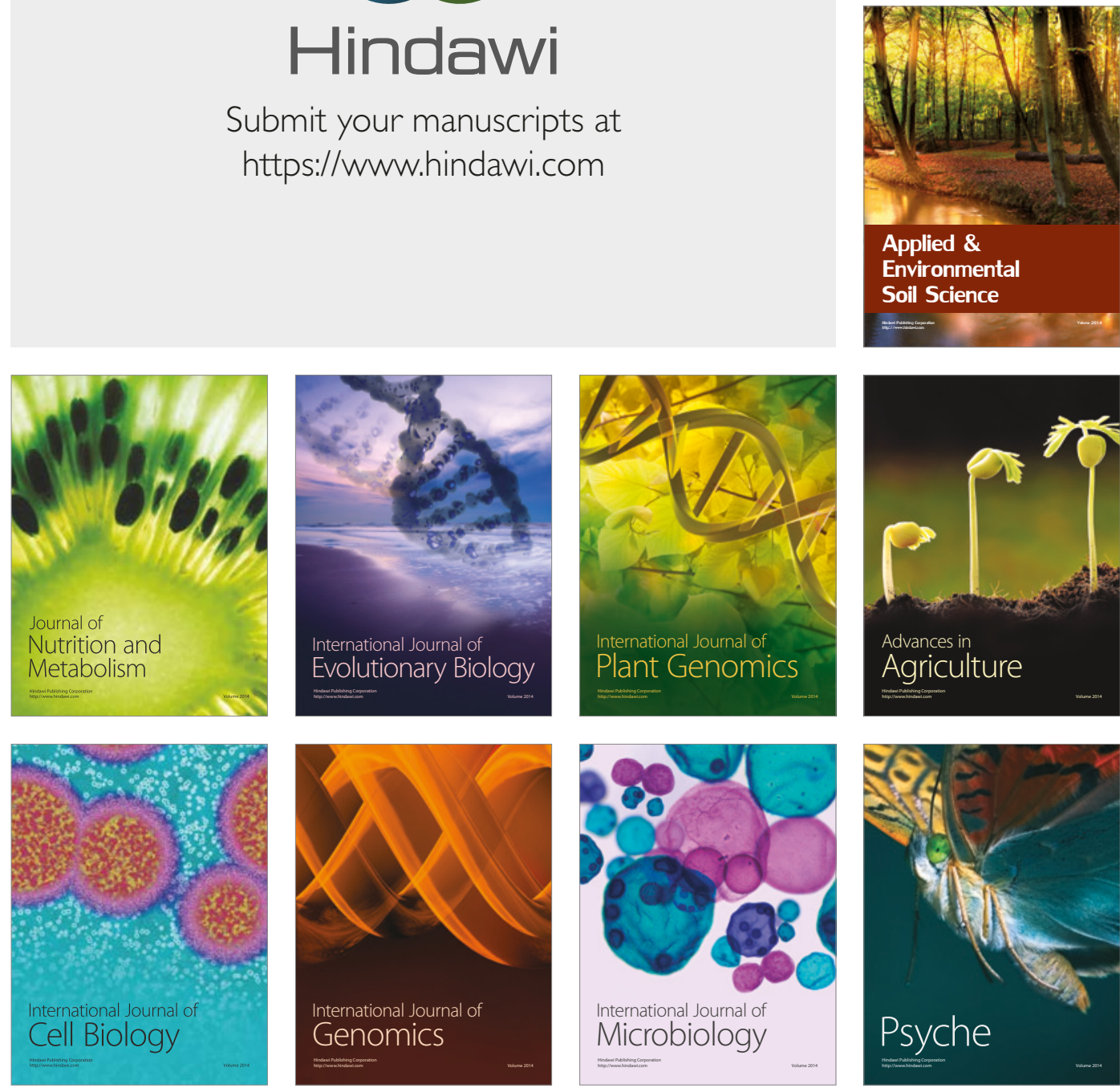

hternational Journal of Microbiology
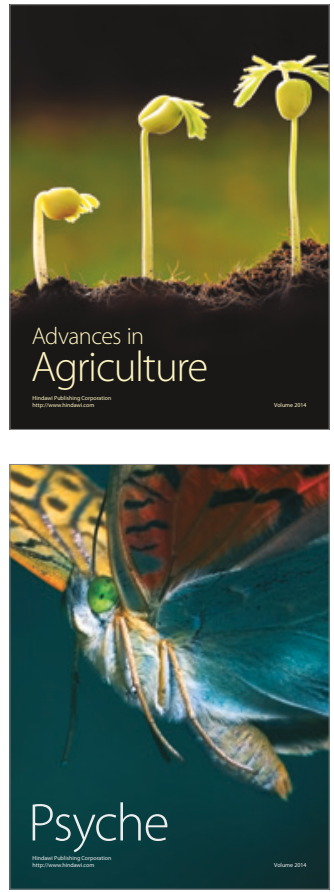